\title{
PROFIL KUALIFIKASI AKADEMIK GURU OLAHRAGA SD SE KOTA TASIKMALAYA
}

\author{
Rahmat Permana \\ Universitas Muhammadiyah Tasikmalaya \\ Jl. Tamansari Gobras. KM. 2.5 \\ Email: Rahmat.pgsd@umtas.ac.id \\ Budi Hendrawan \\ Universitas Muhammadiyah Tasikmalaya \\ Jl. Tamansari Gobras. KM. 2.5 \\ Email: hendrawan_budy@umtas.ac.id \\ Yopa Taufik Shaleh \\ Universitas Muhammadiyah Tasikmalaya \\ Jl. Tamansari Gobras. KM. 2.5 \\ Email: yopa_4474@yahoo.co.id
}

\begin{abstract}
The problem of this research is the profile of academic qualification of PJOK elementary school teacher in Tasikmalaya whose contents of the profile concerning on education background, age and teaching experience. Rresearchers need to reveal how the qualification of PJOK elementary school teachers' profile, whether the educational background in accordance with the subject. The suitability of the educational background will be able to achieve the learning objectives well whereas the teaching experience will determine the teaching skill well. With knowing the profiles, researchers can map the qualifications of PJOK elementary school teachers in Tasikmalaya to be the subject of study in making subjects especially in a field of PGSD PENJAS. The method used in this research is a cross-sectional survey method. In general, data is collected only for a certain time in order to describe the condition of the population. The population in this study is all teachers who teach sports in Elementary School located in the city of Tasikmalaya which amounts to 219 teachers. Samples will be taken by 25 percent of the total population by using simple random sampling. 219 out of $25 \%=54$ teachers who teach sports. The results of this study have determined that the educational background of teachers teaching sports by $100 \%$ is a graduate of the sports studies program, the average age of teachers is 30 years while the teacher's average teaching experience is more than 3 years.
\end{abstract}

\section{Keyword:}

Academic qualification; teaching experience; teachers' profile

\begin{abstract}
Abstrak
Masalah penelitian ini adalah profil kualifikasi akademik guru SD PJOK di kota Tasikmalaya yang isi profilnya mengenai latar belakang pendidikan, usia dan pengalaman mengajar. peneliti perlu mengungkap bagaimana profil kualifikasi guru SD PJOK apakah latar belakang pendidikan sesuai dengan mata ajar. Keseuaian latar belakang pendidikan akan mampu mencapai tujuan pembelajaran secara baik sedangkan pengalaman mengajar akan menentukan keterampilan mengajar dengan baik. Dengan diketahuinya profil tersebut maka peneliti dapat memetakan kualifikasi guru SD PJOK di kota tasikmalaya untuk menjadi bahan kajian dalam membuat mata kuliah konsentrasi khusus bidang PGSD PENJAS. Metode yang digunakan dalam penelitian ini ialah metode survei sekali waktu (cross-sectional survei). Pada umumnya data hanya dikumpulkan untuk waktu tertentu saja dengan tujuan untuk menggambarkan kondisi populasi. Adapun populasi dalam penelitian ini ialah seluruh guru yang mengajar olahraga di Sekolah Dasar yang berada di wilayah kota Tasikmalaya yaitu berjumlah 219 guru. Sampel akan diambil sebesar 25 persen dari total populasi dengan menggunakan simple random sampling. 219 dari $25 \%=54$ guru yang mengajar olahraga Hasil dari penelitian ini memetakan bahwa latar belakang pendidikan guru yang mengajar olahraga sebesar $100 \%$ merupakan lulusan dari prohram studi olahraga, usia rata-rata guru ialah 30 tahun sedangkan pengalaman mengajar rata-rata guru lebih dari 3 tahun.
\end{abstract}

Keyword:

Kualifikasi akademik; pengalaman mengajar; profil guru. 
Rahmat Permana, Budi Hendrawan

Yopa Taufik Saleh
Profil Kualifikasi Akademik Guru Olahraga

SD Se Kota Tasikmalaya

\section{A. PENDAhuluan}

Guru sebagai tenaga pendidik yang bersentuhan langsung dengan peserta didik diwajibkan mempunyai keahlian dibidang akademik atau kualifikasi khusus pada cabang ilmu tertentu. Dengan memiliki kompetensi khusus guru mampu melaksanakan tugas secara maksimal sehingga berdampak pada capaian pembelajaran. Berkaitan dengan kualifikasi guru dalam undang-undang nomer 14 tahun 2005 tentang guru dan dosen "Guru wajib memiliki kualiifikasi akademik, koompetensi, sertifikat pendidik, sehat jasmani dan rohani serta memiliki kemampuan untuk mewujudkan pendidikan nasional". Pada dasarnya ada dua kualifikasi akademik guru yaitu melalui pendidikan formal dan kualifikasi guru melalui uji kelayakan dan kesetaraan.

Pendidikan formal tentu saja dapat dibuktikan dengan ijazah sedangkan uji kelayakan dan kesetaraan diperoleh melalui serifikasi. Adapun Kualifikasi terdiri atas latar belakang pendidikan, usia dan pengalaman mengajar. Profil guru PJOK SD kualifikasinya penting diketahui di daerah kecamatan tamansari Tasikmalaya karena sebelum menuju kota tasikmalaya peneliti bertujuan untuk mendata profil guru PENJASKES di lingkungan kampus yang satu wilayah sehingga peneliti mempunyai gambaran kualifikasi yang nantinya bila perlu akan dibuka mata kuliah konsentrasi PENJAS SD pada program studi PGSD UMTAS.

Pengajar olahraga memerlukan kualifikasi yang sesuai, tidak bisa seorang pengajar olahraga tidak mempunyai bekalilmu pengetahuan yang mendalam mengenai olahraga. Kualifikasi akademik yang relevan memberikan ilmu pengetahuan dan keterampilan untuk setiap materi ajar dan menggunakan berbagai metode pembelajaran dalam proses pembelajaran, memberikan banyak alternatif kepada guru untuk berinisiatif dan berkreatifitas untuk mencapai output pembelajaran sesuai indikator yang telah ada di Silabus dan RPP.

Hasil penelitian Septiana (2010) menunjukan kesimpulan bahwa : 1) ada hubungan antara latar belakang pendidikan guru dengan prestasi belajar siswa, 2) ada hubungan antara pengalaman mengajar dengan prestasi belajar siswa, 3) ada hubungan antara pembelajaran dengan prestasi belajar, dan 4) ada hubungan antara latar belakang pendidikan guru, pengalaman mengajar, dan pembelajaran dengan prestasi belajar siswa. Maka penelitian ini dirasa perlu untuk perkembangan program studi pendidikan guru sekolah dasar sebagai acuan untuk menerapkan mata kuliah konsentrasi PGSD PENJAS yang berdampak pada hasil lulusan yang memiliki kompetensi di bidang pengajaran jasmani dan olahraga.

Pemenuhan standar kualifikasi akademik diatur dalam PERMENDIKNAS nomor 16 tahun 2007 pasal 1 ayat (1) menyatakan "setiap guru wajib memenuhi sttandar kualifikasi akademik dan kompetensi guru yang berlaku secara nasional". aturan tersebut harus dilaksanakan dan dipenuhi oleh semua guru pada seluruh jenjang pendidikan termasuk guru SD PENJASKES.

Kualifikasi akademik guru SD/MI harus memiliki kualifikasi akademik minimum Diploma 4 (D4) atau sarjana (S1) dalam bidang pendidikan SD//MI atau psikologi yang diperoleh dari program studi terakreditasi. Adapun Kualifikasi terdiri atas latar belakang pendidikan, usia dan pengalaman mengajar. Latar belakang pendidikan diharuskan lulusan yang linier dengan bidang keilmuan, usia seorang guru tentunya menentukan kematangan sebagai seorang pengajar profesional sedangkan pengalaman mengajar sangat diperlukan karena evaluasi diri dalam hal skill mengajar dapat terasah pada saat mempunyai pengalaman jam mengajar yang kuantitasnya tinggi. 
Rahmat Permana, Budi Hendrawan

Yopa Taufik Saleh

Penelitian tentang latar belakang pendidikan Gazali (2010), menunjukan bahwa "Latar belakang pendidikan dan pengalaman mengajar berpengaruh positif dan signifikan terhadap profesionalisme guru." latar belakang pendidikan yang linier dengan keilmuan akan memberikan kemampuan perencanaan, pengajaran dan evaluasi dalam pembelajaran sehingga tujuan atauu capaian belajar akan maksimal dan pengalaman mengajar tentunya akan mengasah kemampuan manajerial kelas yang baik serta berkesempatan untuk mendapatkan sertifikasi guru.'Kinerja guru bersertifikasi meliputi aspek perencanaan dan aspek pelaksanaan pengembangan mutu pendidikan telah dilakukan secara efektif dan efsien'.(Shobron,2015).

Guru yang berlatar belakang pendidikan linier sesuai dengan mata pelajaran yang diampu tentunya mempunyai nilai lebih. Hasil riset tentang pengaruh latar belakang pendidikan terhadap prestasi siswa telah banyak diteliti salah satunya Sulthoni (2015) menunjukan secara umum mampu meningkatkan nilai siswa dari aspek kognitif (C1), aspek Pemahaman (C2) dan aspek penerapan (C3). Hal ini mengindikasikan bahwa penghasil-penghasil guru atau LPTK di indonesia harus mennghasilkan calon pendidikan sesuai kondisi di lapangan. Sedangkan guru dengan pengalaman mengajar tentunya akan banyak variasi cara mengajar dari mulai metode hingga evaluasi belajar. Penambahan sertifikat pendidik tentunya bisa menaikan kompetensi sehingga kemampuan guru SD terus meningkat. Aulia (2015) dalam risetnya menyatakan terdapat pengaruh dari pengalaman mengajar terhadap kompetensi profesional seorang guru baik secara parsial maupun simultan.

Pemenuhan standar kualifikasi akademik diatur dalam PERMENDIKNAS nomor 16 tahun 2007 pasal 1 ayat (1) menyatakan "setiap guru wajib memenuhi sttandar kualifikasi akademik dan kompetensi guru yang berlaku secara nasional". aturan tersebut harus
Profil Kualifikasi Akademik Guru Olahraga SD Se Kota Tasikmalaya

dilaksanakan dan dipenuhi oleh semua guru pada seluruh jenjang pendidikan termasuk guru SD PENJASKES.

Kualifikasi akademik guru SD/MI harus memiliki kualifikasi akademik minimum Diploma 4 (D4) atau sarjana (S1) dalam bidang pendidikan SD//MI atau psikologi yang diperoleh dari program studi terakreditasi. Adapun Kualifikasi terdiri atas latar belakang pendidikan, usia dan pengalaman mengajar. Latar belakang pendidikan diharuskan lulusan yang linier dengan bidang keilmuan, usia seorang guru tentunya menentukan kematangan sebagai seorang pengajar profesional sedangkan pengalaman mengajar sangat diperlukan karena evaluasi diri dalam hal skill mengajar dapat terasah pada saat mempunyai pengalaman jam mengajar yang kuantitasnya tinggi.

Penelitian tentang latar belakang pendidikan Gazali (2010), menunjukan bahwa "Latar belakang pendidikan dan pengalaman mengajar berpengaruh positif dan signifikan terhadap profesionalisme guru." latar belakang pendidikan yang linier dengan keilmuan akan memberikan kemampuan perencanaan, pengajaran dan evaluasi dalam pembelajaran sehingga tujuan atauu capaian belajar akan maksimal dan pengalaman mengajar tentunya akan mengasah kemampuan manajerial kelas yang baik serta berkesempatan untuk mendapatkan sertifikasi guru.'Kinerja guru bersertifikasi meliputi aspek perencanaan dan aspek pelaksanaan pengembangan mutu pendidikan telah dilakukan secara efektif dan efsien'.(Shobron,2015)

Guru yang berlatar belakang pendidikan linier sesuai dengan mata pelajaran yang diampu tentunya mempunyai nilai lebih. Hasil riset tentang pengaruh latar belakang pendidikan terhadap prestasi siswa telah banyak diteliti salah satunya Sulthoni (2015) menunjukan secara umum mampu meningkatkan nilai siswa dari aspek kognitif (C1), aspek Pemahaman (C2) dan aspek penerapan (C3). Hal ini mengindikasikan 
Rahmat Permana, Budi Hendrawan

Yopa Taufik Saleh

bahwa penghasil-penghasil guru atau LPTK di indonesia harus mennghasilkan calon pendidikan sesuai kondisi di lapangan. Sedangkan guru dengan pengalaman mengajar tentunya akan banyak variasi cara mengajar dari mulai metode hingga evaluasi belajar. Penambahan sertifikat pendidik tentunya bisa menaikan kompetensi sehingga kemampuan guru SD terus meningkat. Aulia (2015) dalam risetnya menyatakan terdapat pengaruh dari pengalaman mengajar terhadap kompetensi profesional seorang guru baik secara parsial maupun simultan. Penelitian tentang profil guru bertujuan untuk memetakan gambaran umum mengenai latar belakang pendidikan guru yang mengajar olahraga di sekolah dasar wilayah kota Tasikmalaya.

Pendekatan survei adalah salah satu pendekatan penelitian yang pada umumnya digunakan untuk pengumpulan data yang luas dan banyak. sesuai dengan sampel penelitian ini sangat luas yaitu SD se Kota Tasikmalaya. lebih rinci lagi peneliti mengambil jenis survei sekali waktu (cross-sectional survei). data hanya dikumpulkan untuk waktu tertentu saja dengan tujuan untuk menggambarkan kondisi populasi. Populasi adalah wilayah generalisasi berupa subjek atau objek yang diteliti untuk dipelajari dan diambil kesimpulan. Adapun populasi dalam penelitian ini ialah seluruh Sekolah Dasar yang berada di wilayah kota Tasikmalaya berjumlah 219 guru.

Simple random sampling adalah suatu tipe sampling probabilitas, di mana peneliti dalam memilih sampel memberikan kesempatan yang sama kepada semua anggota populasi untuk ditetapkan sebagai anggota sampel. Dengan teknik semacam itu maka terpilihnya individu menjadi anggota sampel benar-benar atas dasar faktor kesempatan, dalam arti memiliki kesempatan yang sama, bukan karena adanya pertimbangan subjektif dari peneliti. Teknik ini merupakan teknik yang paling objektif, dibandingkan dengan teknik-teknik sampling yang lain. Teknik sampling secara random dapat dilakukan dengan menggunakan cara
Profil Kualifikasi Akademik Guru Olahraga SD Se Kota Tasikmalaya

undian. Sampel akan diambil sebesar 25 persen dari total populasi. 219 dari $25 \%=54$ guru yang mengajar olahraga.

Teknik yang digunakan dalam penelitian ini ialah wawancara yang dilakukan secara personal kepada masing-masing guru PJOK. Pewawancara dan responden melakukan tanya jawab secara langsung. mengingat studi survei itu umumnya dilakukan terhadap subyek dalam jumlah besar, biasanya instrumen yang digunakan adalah kuesioner yang berisi butirbutir pertanyaan untuk mengukur dan ada pula yang tidak berfungsi untuk mengukur. 'kuesioner yang mengukur berbentuk skala. adapun kuesioner yang tidak berfungsi mengukur hanya menggali informasi yang terkait dengan masalah survei mealui sejumlah pertanyaan'. (Ali,2011).

\section{B. HASIL DAN PEMBAHASAN}

Hasil rekapitulasi pengumpulan data melalui proses wawancara yang dilakukan terhadap 54 guru pengajar olahraga di kota tasikmlaya dapat dilihat pada tabel 1 .

Tabel 1

Rekapitulasi Hasil Wawancara 54 Guru Pengajar Olahraga

\begin{tabular}{|c|c|c|}
\hline $\begin{array}{c}\text { Latar } \\
\text { Belakang } \\
\text { Pendidikan }\end{array}$ & Usia & $\begin{array}{c}\text { Pengalaman } \\
\text { Mengajar }\end{array}$ \\
\hline $\begin{array}{l}100 \% \\
\text { merupakan } \\
\text { Sarjana } \\
\text { Program } \\
\text { Studi } \\
\text { Pendidikan } \\
\text { Jasmani } \\
\text { dan } \\
\text { Olahraga }\end{array}$ & $\begin{array}{l}\text { Rata- } \\
\text { rata usia } \\
\text { guru } \\
\text { olahraga } \\
\text { ialah } 35 \\
\text { tahun }\end{array}$ & $\begin{array}{l}\text { Pengalaman } \\
\text { mengajar } \\
\text { rata-rata guru } \\
\text { olahraga } \\
\text { ialah lebih } \\
\text { dari } 5 \text { tahun }\end{array}$ \\
\hline
\end{tabular}

\section{Hubungan latar belakang pendidikan dengan profesi sebagai pengajar olahraga}

Undang-undang nomor 14 tahun 2005 tentang guru dan dosen menyatakan bahwa 
Rahmat Permana, Budi Hendrawan

Yopa Taufik Saleh

kualifikasi akademik ialah ijazah jenjang pendidkan akadmik yang dimilki oleh guru atau dosen sesuai dengan jenis, jenjang dan satuan pendidikan formal di tempat penugasan. Pentingnya latar belakang pendidikan dengan bidang studi merupakan keniscayaan terhadap profesi guru pendidikan jasmani dan olahraga di sekolah dasar. Dengan kesusaian ijazah maka kompetensi pedagogik guru akan baik ketika melaksanakan proses pembelajaran olahraga sesuai prinsip-prinsip yang telah didapat pada saat proses perkuliahan.

Profesi sebagai guru olahraga diharapkan menguasai bidang yang terkait dengan pendidikan jasmani atau aktivitas olahraga yang sesuai dengan perkembangan siswa di sekolah dasar. Oleh karena itu, guru pendidikan jasmani tidak sekedar metransfer ilmu, namun pendidikan kebugaran dan menjadikan siswa bergaya hidup sehat. Fenomena yang di lapangan saat ini beberapa guru pendidikan jasmani menempuh pendidikan formal tidak sesuai dengan bidangnya. Hal ini dapat dikarenakan terbatasnya tenaga pendidik pendidikan jasmani di daerah tersebut. Sehingga guru yang berlatar belakan pendidikan bukan dari pendidikan jasmani mengajar penjas di sekolah.

Dari hal tersebut dapat dipastikan pendidikan jasmani menjadi kurang bermanfaat karena guru tersebut kemungkinan hanya mengajarkan kegiatan olahraga secara garis besar atau berdasar apa yang diketahui oleh guru tersebut. Sehingga muncul permasalahan tentang bagaimana pentingnya latar belakang pendidikan yang sesuai bagi seorang pendidik, dalam hai ini adalah seorang guru pendidikan jasmani.

\section{Hubungan usia dan pengalaman pengajar dengan profesi guru olahraga}

Pengalaman mengajar yang dimiliki seorang guru akan membawa manfaat yang sangat besar untuk keberlangsungan proses belajar mengajar yang baik, karena keterampilan memecahkan
Profil Kualifikasi Akademik Guru Olahraga SD Se Kota Tasikmalaya

persoalan dalam proses belajar mengajar olahraga kurang kemungkinan kecil tidak di dapatkan melalui pendidikan formal yang di tempuh, tapi lebih banyak didasarkan pada pengalaman yang telah di dapatkan selama proses kegiatan belajar mengajar di lapangan. Pengalaman-pengalaman bermanfaat yang diperoleh selama mengajar tersebut akan dapat mempengaruhi kualitas guru dalam mengajar. Ngalim Purwanto (2003: 104) mengatakan, "semakin sering seseorang mengalami sesuatu, maka semakin bertambah pengatahuan dan kecakapannya terhadap hal-hal tersebut, dan ia akan lebih menguasai, sehingga dari pengalaman yang diperolehnya seseorang dapat mencoba mendapatkan hasil yang baik."

\section{SIMPULAN}

Berdasarkan hasil penelitian dan pembahasan, dapat diambil kesimpulan sebagai berikut:

1. Dari hasil wawancara pada setiap guru yang mengajar olahraga dapat dipetakan bahwa latar belakang pendidikan guru olahraga di SD wilayah kota tasikmalaya 100 persen sesuai dengan bidang keilmuan. Dengan linieritas tersebut guru telah memenuhi amanat undang-undang guru dan dosen mengenai kualifikasi akdemik yang harus ditempuh.

2. Pengalaman mengajar dan usia di SD wilayah kota tasik menunjukan bahwa ratarata guru sudah lebih dari lima tahun dalam hal lamanya mengajar di sekolah. Dengan demikian akan berpengaruh pada kualitas mengajar dan pemecahan masalah yang akan dihadapi di lapangan.

Berdasarkan tahapan proses penelitian yang dilaksanakan dari tahap pengkajian masalah, tujuan dan pengumpulan data maka di temukan beberapa rekomendasi sebagai upaya perbaikan dalam penelitian ini. Adapun rekomendasi untuk peneliti selanjutnya ialah :

1. Variabel bebas perlu dikembangkan karena kualifikasi guru tidak hanya menitikberatkan pada latar belakang 
Rahmat Permana, Budi Hendrawan

Yopa Taufik Saleh

pendidikan. Ada factor-faktor selain latar belakang pendidikan yang perlu dipetakan

2. Instrumen wawancara terhadap sejumlah guru perlu dikembangkan kembali terkait kesesuaian isi wawancara sehinga kevalidan suatu instrument dapat lebih terukur

3. Penelitian tentang profil bias dihubungkan dengan beberapa variabel terikat seperti hasil belajar, motivasi dan jam waktu aktif belajar.

\section{DAFTAR PUSTAKA}

Ali, M. Memahai Riset Prilaku dan Sosial. Bandung: CV Pustaka Cendeki Utama. 2011.

Aulia. Pengaruh Pengalaman mengajar dan etos kerja terhadap kompetensi profesional guru produktif pemasaran SMK bisnis dan manajemen di kota semarang. Semarang: Universitas Negeri semarang. Lib.Unnes.ac.id. 2015

Gazali. Pengaruh Latar Belakang Pendidikan dan Pengalaman Mengajar

Terhadap Profesionalisme Guru SMK Kompetensi Keahlian Teknik AudioVideo Se Kota Yogyakarta. 2010.

Undang-Undang Dasar. Peraturan Menteri Pendidikan Nasional Nomor 16 Tahun 2007 Pasal 1 Ayat (1). 2007

Septiana. Hubungan Antara Latar Belakang Pendidikan Guru dan Pengalaman

Dengan Prestasi Belajar Siswa Sma Negeri 1 Surakarta. 2015. https://Digilib.Uns.Ac.Id/...=/Hubungan-

Antara- Latar- Belakang

Pendidikan.

Sevilla, Consuelo G. et. al Research Methods. Quezon City: Rex Printing Company. 2007.

Shobron. Kinerja guru bersertifikasi dalam meningkatkan manajmen mutu pendidikan di Madrasah Ibtidaiyah Muhammadiyah Sudung Kedungtuban Blora. tahun 2015. Jurnal
Profil Kualifikasi Akademik Guru Olahraga SD Se Kota Tasikmalaya

sttudi islam, vol. 17, no. 1, juni 2016:57-67 DOAJ Index

Sulthoni. Pengaruh latar belakang pendidikan guru berdasarkan latar belakang pendidikan sarjana terhadap hasil belajar siswa.. Bandung: Universitas Pendidikan Indonesia. 